
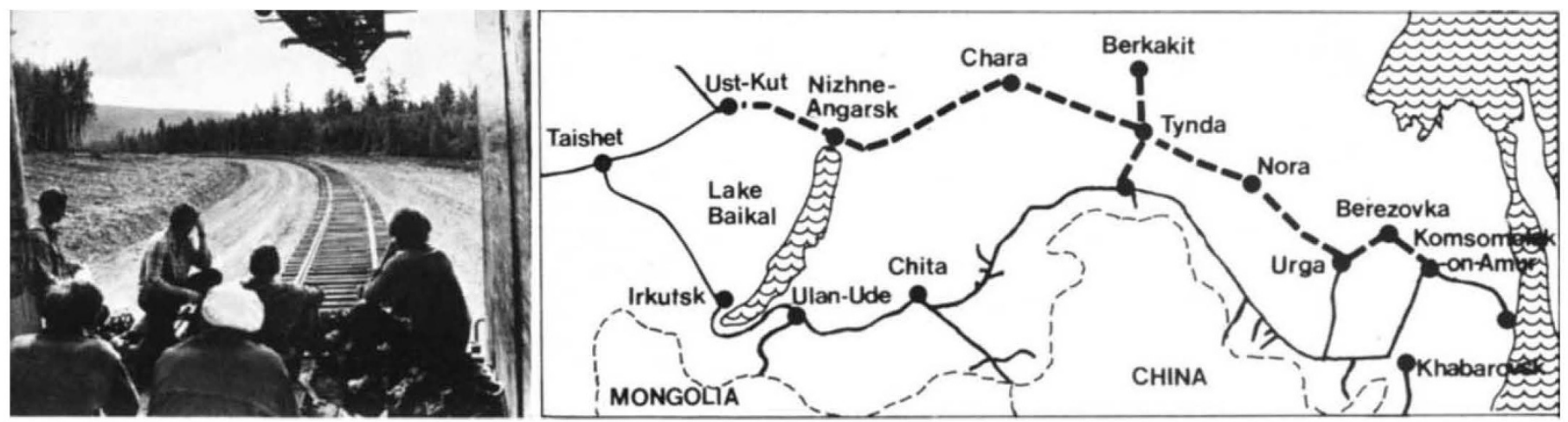

\title{
Baikal railway raises environmental questions
}

"WE are setting aside vast resources for the construction of the BaikalAmur Mainline Railway" said $\mathrm{Mr}$ Kosygin, earlier this month. "Its commissioning will enable the rich natural resources of the trans-Baikal area, southern Yakutia, the Far East and Western Siberia to be more intensively exploited".

BAM - the Baikal-Amur Mainlineis due for completion in 1983. It has considerable symbolic importance to the Soviet planners. Its $3,000 \mathrm{~km}$ of through track (plus spur lines to major coal and ore deposits) will help to open up Siberia by providing a northern alternative to the existing TransSiberian route.

BAM was based on almost 13 years of surveying, before construction was begun in 1974-a survey which made extensive use of satellite photos, incidentally fulfilling Five Year Plan directives that the "exploration of nearEarth space" should be used "in the interests of the national economy".

Numerous research bodies were drawn into the planning of the project. A major role was played by the various institutes of the Siberian branch of the Soviet Academy of Sciences and the Far Eastern Science Centre. The Institute of Siberian and Far Eastern Geography has mapped the plant distribution of the BAM zone, classifying the various natural regions and determining the plant resources and the role of plants in erosion protection.

The same institute has also made a detailed survey of meteorological conditions, especially avalanches, in the
Kodar and Udokan ranges, while the Institute of Geology and Geophysics of the Siberian branch of the Academy has been working on tectonic movements. Preliminary results have been somewhat surprising. In the region of Lake Baikal, the rate of vertical movement of the crust appears to exceed that in the Caucausus, increasing northwards, so that Irkutsk is rising at $8 \mathrm{~mm}$ per year, and Nizhne-Angarsk (a station on BAM) at $19-20 \mathrm{~mm}$.

Since the BAM zone is so highly seismic, the Institute of the Earth's Crust of the Siberian branch of the Academy developed a network of automatic seismic stations. So far, some 3,500 weak tremors have been registered and the system is shortly to be extended. Using aerial and satellite photography and computer simulation, a team from Alma-Ata are mapping sites of potential mud torrents in the future BAM industrial zone.

In addition to this seismic expertise, there have been several less expected spin-offs from BAM. One of the most interesting occurred on the section between the Baikal and Severomuisk tunnels, where the incursion of modern man turned up traces of primitive man, who, it would seem, first appeared in the area some 180,000 years ago.

Apart from problems directly connected with construction, however, the main direction of research has been ecology and conservation. From the beginning, BAM was planned with considerable respect for the environment. At times, the precautions seemed almost ludicrous, as when construction workers

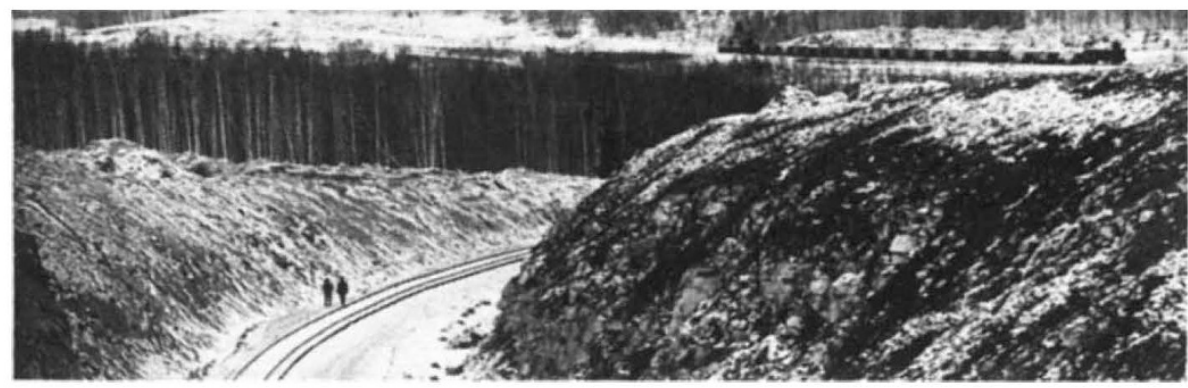

The Baikal-A mur railway: route to the wealth of Siberia were forbidden to use pesticides against the swarms of mosquitos which ruin the Siberian spring.

For the most part, though, the ecological planning was serious and well-founded. Round the northern shore of Lake Biakal, the original plan called for either a shore tunnel or else for the track to be laid along the actual shore of the lake. In the interests of conservation, however, it was finally decided to tunnel through the solid rock, to protect the lake from debris.

$A$ vast nature reserve has been set aside in the BAM zone, including coniferous and mixed forest, mountains, rivers, lakes and alpine meadows. Fauna thus protected include wild elk, reindeer, black stork, white tailed sea-eagle, sable, brown bear, ermine and lynx. New legislation will ensure adequate crossing points for migrating animals to traverse BAM.

Planning is going forward, too, for the ecology of the future settlements of the area. Industrial complexes will be surrounded by green belts. According to Academician Brezhnev, Director of the Plant Breeding Institute of the All-Union Academy of Agricultural Sciences, "specialised farms" are to be set up along the route, which will produce fresh produce all the year round for the new towns. Sociological problems of life in remote settlements, and estimates of requirements in housing, education and recreation facilities are well under way.

However, perhaps the most unlikely spin-off from BAM is the tacit acceptance, in mass-media reports, that the seismic problems of the zone are due to plate tectonics. Until recently, Soviet geologists have been reluctant to commit themselves publicly to plates, due to the opposition of the prestigious Academician Belousov. Recent TASS releases, however, accept plate tectonics as an accepted feature of the BAM zone. Indeed, TASS reported last January that, owing to plate movements, by the end of the century, BAM will be some $50 \mathrm{~cm}$ longer than planned.

Vera Rich 